\title{
Democracia e ditadurano Brasil e na Argentina: o papel dos intelectuais
}

Claudia Wasserman*

$\mathrm{O}$ artigo trata do papel desempenhado pelos intelectuais brasileiros e argentinos no contexto das transições à democracia nos anos 1980. Aborda o processo de transição nos dois países, o contexto cultural da época, o retorno do exílio dos intelectuais e os temas por eles discutidos naquele período.

Palavras-chave: Anos 1980; Transição Democrática; Historia Intelectual

The article discusses the role played by Brazilian and Argentine intellectuals in the context of transitions to democracy in the 1980s. Discusses the transition process in the two countries, the cultural context of the period, the return of intellectuals from exile and the issues discussed by them at that time.

Keywords: 1980'; Democratic Transition; Intellectual History ambiente cultural e o contexto intelectual dos anos 1980 no Brasil e na Argentina estiveram marcados pela transição democrática. Os anos de ditadura autoritária e depois a transição democrática provocaram mudanças profundas no campo intelectual e cultural das sociedades latino-americanas. A transição tinha um significado fundamental para as sociedades sul-americanas: tratava-se do encerramento de uma época marcada pela perseguição a inimigos internos identificados com o

\footnotetext{
*Dra. História Social (UFRJ), Professora Associada UFRGS, claudia.wasserman@ufrgs.br
} 
comunismo, com a implantação do socialismo ou com o nacionalismo extremado. Com a crise da ditadura e com a instauração da democracia estes supostos inimigos reapareciam no cenário político ou retornavam do exílio. O medo, um espectro existente em todo o período autoritário, esteve também muito presente na época das transições, por volta dos anos 1980/90: a direita tinha medo de avanços radicais e a esquerda temia um retrocesso ao autoritarismo. Neste sentido, o medo que no período ditatorial desempenhou um papel importante na contenção ou na eliminação dos inimigos internos, vai atuar de modo muito significativo nas transições à democracia, assim como na instauração de políticas de passado. A memória da ditadura ficou, portanto, encapsulada nesta trama dos temores e receios envolvidos no período da transição.

A pesquisa que dá origem a este artigo pretende examinar o papel desempenhado pelos intelectuais latino-americanos, sobretudo no Brasil, Chile, Argentina e Uruguai no contexto das transições democráticas dos anos 1980, no que diz respeito ao resgate da memória das ditaduras, aos projetos conciliatórios, à instauração de políticas de reparação, à justiça de transição e às políticas de desmemoria. Neste artigo, reproduzo uma parte da pesquisa que diz respeito aos intelectuais argentinos e brasileiros, o ambiente cultural nos dois países no período da transição e os temas prediletos debatidos pelos intelectuais argentinos e brasileiros naquele contexto.

Artistas e intelectuais formaram os grupos que mais se viram desafiados pela necessidade de revisar suas concepções de mundo. Muitas das certezas, relacionadas com os projetos intelectuais anteriores ao golpe, foram irremediavelmente abaladas. Os intelectuais e artistas em geral tiveram que se adaptar a uma nova cultura política democrática e às transformações no ambiente cultural que se tinham operado durante a sua ausência.

O retorno dos exilados foi um dos elementos a contribuir para a caracterização da cultura política das sociedades sul-americanas nesse período. De um lado, lembravam a efervescência do período anterior à ditadura e, por outra parte, confrontavam-se com uma sociedade totalmente diferente daquela que haviam deixado quando partiram para o exílio. Os intelectuais 
que estiveram exilados durante as ditaduras retornaram aos países de origem e tiveram que se adaptar às novas estruturas. $\mathrm{O}$ artigo procura abordar as transformações e o estranhamento provocados pelo retorno a condições adversas nos dois países. Procurar-se-á fazer essa análise através de uma descrição dos processos de transição nos dois países, uma investigação sobre o ambiente intelectual e artístico e também trazer a tona as preocupações intelectuais, através dos depoimentos dos que retornaram do exílio e dos que permaneceram na sombra durante a ditadura.

\section{Brasil e Argentina nos anos 1980}

Os anos anteriores aos golpes haviam sido de intensa atividade cultural nos dois países, Argentina e Brasil. Ao longo do período ditatorial, essa efervescência cultural foi se retraindo, até desaparecer quase integralmente. Nos anos 1980, os lugares de sociabilidade da intelectualidade e dos artistas, que existiam antes dos golpes, tinham se modificado, alguns dos quais desapareceram. $\mathrm{O}$ ambiente das revistas culturais e políticas que existiam antes da implantação das ditaduras tinha se modificado e as universidades já não eram mais as mesmas. Em geral, os intelectuais e artistas brasileiros e argentinos saíram de países tensionados entre a esquerda revolucionária e a direita autoritária, e retornaram a países marcados pelo apelo à redemocratização como eixo central de todas as tendências político-ideológicas. Além disso, a queda do socialismo abalara de modo incontornável os meios intelectuais de esquerda, justamente os que sofreram o exílio que se viram desafiados a compreender a socialdemocracia europeia e o eurocomunismo.

A visão do protótipo do artista ou do intelectual dos anos 1960/70 como o sujeito com uma postura engajada, de esquerda e quase sempre revolucionária, sofrera um revés enorme nos anos 1980. Postulava-se, no período de redemocratização, que os intelectuais e artistas devessem seguir um padrão mais autônomo e democrático. A arte engajada cedeu espaço à valorização da estética pura; a intelectualidade comprometida com causas sociais deu lugar a intelectuais comprometidos com causas mais difusas ou 
muito particulares. Mudaram as instituições, transformaram-se os contextos políticos e mudaram os intelectuais e artistas.

Os exilados, aqueles que tinham a idílica noção de retornar à condição anterior sofreram um baque muito grande e tiveram que se adaptar. Voltar ao seu próprio país depois de anos vivendo no exílio foi uma experiência dolorosa para todos os que tiveram que deixar o Brasil depois de 1964 e os que deixaram a Argentina depois de 1966/76. Os exilados intelectuais brasileiros e argentinos foram em geral bem acolhidos nas universidades mexicanas, chilenas, norte-americanas e europeias, e, por isso, no retorno, tiveram um estranhamento ainda maior ${ }^{1}$. A mudança nos ambientes profissionais e na cultura política do Brasil e da Argentina era evidente e correspondia às transformações ocorridas no âmbito internacional e interno.

As sucessivas crises do petróleo (1973 e 1978) prenunciavam os percalços econômicos do mundo capitalista nos anos 1980 que iniciaram marcados pelas eleições de Margareth Tatcher no Reino Unido e de Ronald Reagan nos Estados Unidos, pela fundação do Sindicato Solidariedade na Polônia e que tiveram seu desfecho marcado pela queda do Muro de Berlim e pela reunificação da Alemanha. Internacionalmente, a década de 1980 foicaracterizada pela ascensão e pelo predomínio do neoliberalismo como doutrina econômica e pelo conservadorismo no campo político. Considerada como a "década perdida", os anos 1980 anunciavam o início da crise do socialismo, a vitória do pensamento único e o fim da história ${ }^{2}$.

$\mathrm{Na}$ América Latina, a contrapelo das tendências internacionais, os movimentos de resistência às ditaduras se intensificaram e os regimes militares apresentavam os primeiros sinais de enfraquecimento. No Brasil, houve o

\footnotetext{
${ }^{1}$ Para ver mais sobre os exílios na América Latina, ver FERNANDEZ, Jorge Christian. Anclaos em Brasil: a presença argentina no Rio Grande do Sul (1966-1989). Doutorado em História. Programa de Pós-Graduação em História, UFRGS, Porto Alegre, 2011.

${ }^{2}$ A vitória do pensamento único refere-se ao coroamento do capitalismo como sistema dominante no mundo e seu triunfo sobre a alternativa socialista. O fim da história foi uma expressão cunhada por Hegel para designar momento em que a humanidade encontraria um regime mais duradouro. Foi retomada pelo norte-americano Francis Fukuyama para designar o triunfo do capitalismo.
} 
crescimento do proletariado urbano, protagonista de cinco greves gerais entre 1983 e 1989, a criação do Partido dos Trabalhadores (PT) em 1980 e a fundação da Central Única dos Trabalhadores (CUT) em 1983. Na Argentina o movimento de direitos humanos se expandiu. Partidos políticos e sindicatos convergiram para as demandas e denúncias de movimentos como, por exemplo, a "Marcha por la Vida", de 05 de outubro de 1982, e da Associação das Madres da Plaza de Mayo. A reorganização da União Cívica Radical (UCR) em torno de Raúl Alfonsín e do "Movimiento de Renovación y Cambio" foram igualmente importantes para a desestabilização do regime.

Do ponto de vista econômico, os anos 1980 foram marcados por forte estagnação na América Latina, fase de intensa retração da atividade industrial. Nesse sentido, os intelectuais e políticos brasileiros e argentinos deixaram seus países onde, na década de 1950-60, predominavam perspectivas otimistas sobre o desenvolvimento da economia e retornaram sob uma forte crise de realização da atividade industrial, crise da divida externa, indíces altissimos de inflação e grave desemprego.

Políticamente, o debate sobre a redemocratização predominava nas sociedades brasileira e argentina. No Brasil, o governo dos militares, sob o comando do general João Batista Figueiredo, emitia os primeiros e mais consistentes sinais de retorno dos militares aos quartéis. O AI5 foi revogado em janeiro de 1979, a Lei da Anistia promulgada em agosto e, em dezembro, foi promulgada a "Nova Lei Orgânica dos Partidos Políticos" que extinguia ARENA e MDB e instituía o pluripartidarismo, abrindo caminho para a criação de vários partidos contemplando a diversidade de opositores do regime militar.

Na Argentina, o governo das juntas militares também apresentava sinais de esgotamento, em grande parte devido às pressões econômicas e desentendimentos entre os militares. O fim da ditadura foi, entretanto, precipitado pela guerra das Malvinas. A invasão das ilhas, em abril de 1982, foi uma tentativa de estender a ditadura militar já desgastada. A derrota na guerra para o Reino Unido em junho apressou o fim do regime. O então chefe da junta militar, Leopoldo Galtieri, foi substituído e foram convoca- 
das eleições para a presidência, que transcorreram em outubro de 1983. Em março de 1983, diante da possibilidade de julgamento dos crimes cometidos pelos agentes da ditadura, foi decretada a lei de auto-anistia. O colapso abrupto da ditadura argentina impediu a organização dos civis e impediu uma transição orientada pela oposição ao regime ${ }^{3}$.

\section{A redefinição do papel dos intelectuais}

Para todo o universo da esquerda brasileira e argentina, especialmente para os exilados, o panorama era de cautela e de reconhecimento da situação, fase de lenta adaptação e gradual reinsersão depois de tão prolongada ausência. Afinal, foram anos sem pisar na terra natal, sem saber exatamente o quanto tinham sido transformados os costumes, a cultura do país e também quais eram os critérios atuais de excelência nos ambientes acadêmicos e profissionais que eles haviam frequentado antes da ditadura.

Daniel Aarão ${ }^{4}$, em um capítulo do livro Intelectuais: sociedade e política refere-se ao problema do retorno do exílio. Na apresentação parcial dos resultados das entrevistas realizadas com Vera Sílvia Araújo Magalhães, militante considerada pelo autor como emblema brasileiro desta geração, Aarão destaca a participação política e intelectual de quem esteve "na linha de frente" da rebeldia dos anos 1960; sofreu o "exílio de amarguras, dúvidas e desesperos, como sempre, mas também de muita criatividade"; e voltou ao país com a anistia: "um país outro, transformado pelos anos de ditadura, outras gentes, outras expectativas, diferentes circunstâncias internacionais".

Utilizando como exemplo a história de Albert Camus do livro "O Estrangeiro", Reis ressalta que "Vera sentiu-se estranha. Uma étrangeté que, a

\footnotetext{
${ }^{3}$ NOVARO, Marcos, PALERMO, Vicemte. A ditadura militar argentina (1976-19830. Do golpe de Estado à restauração democrática. São Paulo:Edusp, 2007, p. 617.

${ }^{4}$ REIS, Daniel Aarão. A Vera. In BASTOS, E. R., RIDENTI, M., ROLLAND, D. (Orgs.). Intelectuais: sociedade e política. São Paulo: Cortez, 2003.
} 
rigor, a perseguia há longo tempo"s. Segundo Aarão, Étrangeté se refere ao estranhamento: "Estar sem estar, estar de um modo desconfortável, como se estivesse fora do lugar onde deveria estar, e, no entanto, o lugar é este mesmo onde se está, muito familiar, o que não quer dizer que seja amigável, ou acolhedor, apenas familiar, e, súbito, a percepção de uma difícil inserção..."

O retorno evidenciava o descompasso, o estranhamento e condicionava um retorno ao passado; levava a um questionamento dos motivos que induziram à saída do país: “... na volta ao país... no reencontro..., quando se tornou imperioso o aggiornamento, a estranheza apareceu em todo o seu esplendor, e em todo o seu desconforto, iluminando as raízes da rebeldia, no passado longínquo, evidenciando as razões profundas da inadaptação do exílio, e os descompassos inevitáveis que acompanhariam sua trajetória...”7.

Os exilados encontraram inequivocamente países diferentes daqueles que sofreram os golpes militares. Acometidos pela crise econômica internacional e pela crise da dívida externa, Brasil e Argentina contavam com uma nova configuração político-partidária e os debates giravam em torno da democracia, com abandono gradual de discussões sobre qualquer alternativa ao capitalismo e à democracia burguesa. $\mathrm{O}$ ensino superior havia se massificado; nas ciências sociais e humanidades havia se rompido o paradigma epistemológico da modernidade que vigorara até então.

Geoff Eley ${ }^{8}$ faz referência à necessidade que a esquerda europeia teve de repensar suas próprias concepções nos anos 1980, constituindo-se, segundo o seu ponto de vista, em "um enorme desafio às premissas tradicionais", observação que é pertinente também para a esquerda latino-ameri-

${ }^{5}$ Idem, pp. $246 / 7$.

${ }^{6}$ Idem, p. 252.

${ }^{7}$ Idem.

${ }^{8}$ ELEY, Geoff. Forjando a democracia: a história da esquerda na Europa, 1850-2000. São Paulo: Fundação Perseu Abramo, 2005. 
cana como um todo: "A crise do socialismo dos anos 1980 não somente impôs repensar as fronteiras e os significados da esquerda, as necessidades da democracia e a própria natureza da política em si, mas também compeliu os historiadores a levar as mesmas questões de volta ao passado".

Eley alude a sua própria tentativa de, como historiador durante a escrita do livro, "captar o drama de uma transição contemporânea ainda em andamento"10 e a constatação das "agonias da epistemologia", "frustrações da teoria" ". Essa sensação de um mundo em transformação e de insegurança atingiu todas as ciências sociais e humanidades, sobretudo entre os intelectuais da América do Sul, onde as transformações tiveram intensidade ainda maior. Roxana Patiño ${ }^{12}$ analisa a transição argentina e as transformações operadas no campo cultural e intelectual do país nos anos 1980 e adverte: "elintelectual de latransición que piensacómo reconstruir una cultura lohace articuladamente conlaproducción de una nueva cultura política"13.

O declínio da ditadura e a necessidade de afirmação de uma cultura democrática, ainda que imersa em um ambiente com fortes resíduos autoritários, exigiu uma redefinição do papel dos intelectuais, ao mesmo tempo em que tornou residuais as perspectivas que se inspiravam em uma cultura política revolucionaria, hegemônica nos anos 1960 e 1970. O intelectual engajado e comprometido com a revolução dos anos 1960-70 perdeu espaço, foi obrigado a revisar sua concepção de mundo. Houve uma relativa inadequação teórica - a epistemologia da modernidade passava por graves questionamentos diante da valorização do relativismo - como também se

${ }^{9}$ Idem, p. 14.

${ }^{10}$ Idem.

${ }^{11}$ Idem, p. 15.

${ }^{12}$ PATIÑO, Roxana. Culturas em transición: reforma ideológica, democratización y periodismo cultural em la argentina de los achenta. Revista Interamericana de Bibliografia. 1998. n. II. In HTTP://www.educoas.org/portal/bdigital/contenido/rib/rib_1998-2/articulo12/index.aspx? culture=pt\&navid=230, acesso em 11 de dezembro de $201 \overline{2}$.

${ }^{13}$ Idem, p. 01. 
criou uma nova cultura política que exigia mais atenção aos problemas de ordem prática e mais independência para proceder a debates sobre a democratização, a via político-partidária, a constituinte etc. O processo de recolocação de intelectuais e artistas nessa nova realidade esteve influenciado, portanto, por esses novos valores, hierarquias e necessidades.

A produção dessa nova cultura política exigiu dos intelectuais uma adesão mais consistente à via institucional e um abandono das alternativas insurrecionais que haviam vigorado entre uma parte da intelectualidade de esquerda no período imediatamente anterior aos golpes militares e logo após o acirramento dos regimes autoritários, além de um exame dos equívocos do passado.

Esse ambiente, que contemplava a revalorização da democracia e das vias institucionais, informado pela crise do paradigma da modernidade, atinge toda a esquerda brasileira e argentina, tanto aquela que permaneceu no país, como a que estava no exílio. Segundo Patiño: "la apertura de la esfera pública durante la transición y la llegada de los exiliados al país... permite poner en contacto circuitos intelectuales y diferentes modos de procesar los años de la dictadura." ${ }^{14}$.

$\mathrm{O}$ afastamento relativo vivido pelos exilados e a necessidade de acomodar-se à cultura autoritária por parte dos que permaneceram no país parecem dividir a esquerda. Rollemberg ${ }^{15}$ também faz uma distinção entre os exilados e os que permaneceram no país: "As esquerdas que retornaram do exílio enfatizaram as rupturas, percebendo menos as continuidades, compreendendo mal as modernizações pelas quais o país passara nos anos de ditadura, pouco sabendo sobre a sociedade com a qual lidariam nos anos seguintes, ignorando a zona cinzenta na qual ficara a enorme maioria dos brasileiros nos últimos 21 anos. Um passado incontornável no presente." ${ }^{\prime 1}$.

\footnotetext{
${ }^{14}$ Idem, p. 03.

${ }^{15}$ ROLLEMBERG, Denise. Memórias no exílio, memórias do exílio. In FERREIRA, J. \& REIS, D. A. As esquerdas no Brasil. Revolução e democracia. 1964... Rio de Janeiro: Civilização Brasileira, 2007.
}

${ }^{16}$ Idem, p. 213-214. 
A intelectualidade de esquerda, sobretudo aquela que havia permanecido no Brasil e na Argentina durante a ditadura, foi forçada a se acomodar à realidade autoritária. De um lado, os intelectuais de esquerda, que viveram o período autoritário internamente, se impuseram uma espécie de autocensura procurando evitar a repressão, driblar a censura e, no limite, se manterem vivos. De outro lado, produziu-se uma crítica aos movimentos guerrilheiros, acusados de impedir a negociação de retorno à democracia.

Porém, a adaptação à nova realidade, ao processo de redemocratização, foi um empreendimento de todos os grupos de esquerda, daqueles que permaneceram no Brasil ou na Argentina resistindo nas franjas do regime autoritário e sujeitos à repressão, censura e autocensura, mas também foi um imperativo para os que retornaram do exílio ou saíram das sombras depois da anistia. Segundo Rollemberg, os que voltaram do exílio tinham uma imagem de que "a sociedade era submetida a ferro e fogo pelos militares, o que nem de longe correspondia à realidade" ${ }^{17}$. Em função dessa imagem distorcida, Rollemberg corrobora a ideia de que “... muitos viveram como drama a constatação de que o país se transformara... os anos de reintegração ao país foram difíceis, de adaptação, de reconstrução, como fora o próprio exílio." ${ }^{18}$.

\section{Esperança, ilusão e frustração diante da democracia}

Os intelectuais que reapareciam no cenário cultural do Brasil e da Argentina nos anos 1980, retornando do exílio ou simplesmente retomando seu papel de intervir nos debates da sociedade tinham sentimentos variados em relação aos novos regimes. De um lado, despontou com muita força o alívio pela crise das ditaduras. De outra parte, apareciam igualmente muitasdúvidas em relação aos novos regimes.

\footnotetext{
${ }^{17}$ Idem, p. 202.

${ }^{18} \mathrm{Idem}$.
} 
Beatriz Sarlo ${ }^{19}$, por exemplo, oferecia uma imagem esperançosa diante da derrocada da ditadura e da inauguração de novos tempos, que, segundo ela mesma, desfez-se muito rapidamente: “... quase todos acreditavam que estava chegando um longo período de bem-estar social. Acreditava-se que, se havíamos sido capazes de reinstalar as instituições, poderíamos também reconstruir a Argentina com a qual sonhávamos, um país industrializado no qual haveria um alto padrão de consumo. As coisas não foram bem assim, mas vivemos durante alguns anos mergulhados na ilusão."

A descrença em relação à transição não foi imediata, mas se fez sentir nos meios intelectuais brasileiros e argentinos: "Em um simpósio sobre a transição brasileira, realizado em inícios de 1987 na Universidade de São Paulo, Guillermo O'Donell afirmou que a transição brasileira estaria ameaçada de 'morte lenta'. ... Diga-se de passagem que, pessimista em relação ao processo brasileiro, O' Donell não chega a ser propriamente otimista em relação às possibilidades da transição em seu próprio país, a Argentina" ${ }^{20}$.

Nos dois países, a promulgação de leis de anistia permitiu o retorno dos exilados, mas as leis determinaram também a impunidade para os crimes cometidos pelos agentes da repressão e foram responsáveis pela interdição do passado. No Brasil, houve um planejamento minuciosamente arquitetado para que a interdição ao passado e a impunidade fossem imediatas e permanentes, sendo a redemocratização e a nova Constituição os eixos que articulavam os debates. Na Argentina, houve a precipitação do fim da ditadura, sem que os órgãos de repressão e o regime pudessem planejar o processo tal como ocorreu no Brasil. A centralidade dos debates recaiu, então, sobre a questão dos direitos humanos e o julgamento dos crimes cometidos pela ditadura. Isso explica as diferenças entre a sensação de entusiasmo dos argentinos e a cautela dos brasileiros em relação ao processo de redemocratização.

\footnotetext{
${ }^{19}$ SARLO, Beatriz. Tempo presente: notas sobre a mudança de uma cultura. Rio de Janeiro: José Olympio, 2005.

${ }^{20}$ WEFFORT, F., In MOISÉS, J. A., ALBUQUERQUE, J. A. G. Dilemas de consolidação da democracia. Rio de Janeiro: Paz e Terra, 1989, p. 72.
} 
Os intelectuais brasileiros que por motivos político-ideológicos deixaram o país depois do golpe de 1964, puderam retornar após a promulgação da Lei da Anistia de 28 de agosto de $1979^{21}$. Os primeiros exilados célebres a retornar ao país foram Leonel de Moura Brizola, ex-governador do Rio Grande do Sul, e Miguel Arraes, ex-governador de Pernambuco. Brizola entrou no Brasil por Foz do Iguaçu no dia 06 de setembro de 1979 e falou pouco, deixando claro que aqueles que o seguissem no retorno ao Brasil deveriam ter "cautela, paciência e prudência" (site do Partido Democrático Trabalhista (PDT), acesso em março de 2012). Era o primeiro sinal de que se abria no país um período de conciliação nacional prudentemente articulado pelas forças conservadoras para impedir a crítica ao período anterior.

De acordo com o cientista político brasileiro José Álvaro Moisés ${ }^{22}$, “... a transição política brasileira caracterizava um caso bem sucedido daquilo que se tem chamado de 'transições pactadas', ou seja, de casos em que um amplo processo de entendimentos e de negociações, explícitas ou não, entre os 'brandos' dos regimes autoritários e os 'moderados' das oposições democráticas acabaram por conduzir às saídas negociadas do autoritarismo..." ${ }^{23}$.

$\mathrm{Na}$ Argentina foi decretada em março de 1983 a Ley de Autoamnistia, no 22.924, segundo a qual os crimes cometidos entre 1973 e 1982, por motivação terrorista ou subversiva, estavam extintos ${ }^{24}$. O decreto também

${ }^{21}$ A Lei da Anistia, $\mathrm{n}^{\circ}$ 6.683, foi promulgada pelo presidente João Batista Figueiredo em de 28 de agosto de 1979, ainda durante a ditadura militar, estabelece: "Art. $1^{\circ}$ É concedida anistia a todos quantos, no período compreendido entre 2 de setembro de 1961 e 15 de agosto de 1979, cometeram crimes políticos ou conexo com estes, crimes eleitorais, aos que tiveram seus direitos politicos suspensos e aos servidores da Administração Direta e Indireta, de fundações vinculadas ao poder público, aos Servidores dos Poderes Legislativo e Judiciário, aos Militares e aos dirigentes e representantes sindicais, punidos com fundamento em Atos Institucionais e Complementares..." $\S 1^{\circ}$ - Consideram-se conexos, para efeito deste artigo, os crimes de qualquer natureza relacionados com crimes políticos ou praticados por motivação política."

${ }^{22}$ MOISÉS, José Álvaro. Dilemas da consolidação democrática no Brasil. In Moisés, J. A. \& ALBUQUERQUE, J. A. G. Dilemas da consolidação da cemocracia. Rio de Janeiro: Paz e Terra, 1989.

${ }^{23}$ Idem, p. 138

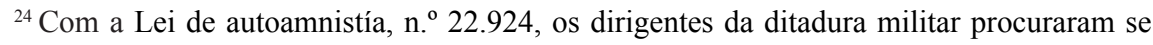
200 
fazia a ressalva de que estavam excluídos dos benefícios da lei os membros de associações ilícitas, terroristas ou subversivas. Os delitos relacionados com o "combate à subversão", no entanto, não poderiam ser interrogados, investigados e indiciados ${ }^{25}$. O decreto, lançado nove meses antes de terminar a ditadura, foi derrubado pelo governo Raúl Alfonsín ${ }^{26}$.

Assim, ao iniciar o período de redemocratização, Brasil e Argentina viveram situações bastante desiguais no que se refere ao ajuste de contas com o passado. A "cautela, paciência e prudência" anunciadas por Leonel Brizola, este considerado pelas Forças Armadas brasileiras um dos mais "perigosos" inimigos do regime, não fizeram parte do vocabulário dos novos mandatários argentinos a partir da queda da ditadura.

Segundo Carlos Altamirano ${ }^{27}$, sociólogo argentino, um dos fundadores da revista Punto de Vista: "Luego se precipita la crisis del régimen militar, se produce esa salida sin pacto,... A partir de 1983 comienza a regresar la mayoría de la gente que estaba en México nucleada alrededor de la revista Controversia y, junto con ellos, fundamos el Club de Cultura Socialista en el año 1984. La fundación del Club de Cultura Socialista estuvo muy

proteger, diante da possibilidade de serem julgados pelo governo democrático. O Artigo $\mathrm{n}^{\mathrm{o}}$ 1 da Lei declarava: "Declárense extinguidas las acciones penales emergentes de los delitos cometidos con motivación o finalidad terrorista o subversiva, desde el 25 de mayo de 1973 hasta el 17 de junio de 1982. Los beneficios otorgados por esta ley se extienden, asimismo, a todos los hechos de naturaleza penal realizados en ocasión o con motivo del desarrollo de acciones dirigidas a prevenir, conjurar o poner fin a las referidas actividades terroristas o subversivas, cualquiera hubiera sido su naturaleza o el bien jurídico lesionado. Los efectos de esta ley alcanzan a los autores, partícipes, instigadores, cómplices o encubridores y comprende a los delitos comunes conexos y a los delitos militares conexos."

${ }^{25}$ LEIS, Héctor. El movimiento por los derechos humanos y la poliica argentina I y II. Buenos Aires: Centro Editor, 1989.

${ }^{26}$ Raúl Alfonsín, candidato às eleições de 1983 na Argentina pela União Cívica Radical, posicionou-se desde o período eleitoral contrário à continuidade da Lei de Auto-anistia e comprometeu-se a extingui-la caso fosse eleito. Assim que assumiu a presidência, Alfonsín enviou para o Congresso um projeto de lei, em seguida aprovado, Lei n. ${ }^{\circ} 23.040$, tornando sem efeito a Lei de Auto-anistia.

${ }^{27}$ ALTAMIRANO, Carlos. El intelectual em La represión y em la democracia. In Revista Punto de Vista, n. 28 (1986). 
ligada al clima alfonsinista, a las expectativas que se habían generado en torno al alfonsinismo..."28.

No período imediatamente posterior à queda das ditaduras, duas posições vinculadas entre si ressoaram com muita força entre os intelectuais: uma propensão para esquecer o passado, de um lado, e, de outra parte, a imposição da legitimação da democracia.

Intelectuais e cientistas sociais desempenharam um papel chave na elaboração de versões sobre o passado autoritário e foram importantes porta-vozes da sociedade civil para implantação dos regimes democráticos. Mas, suas manifestações, ainda que informadas pelo conhecimento que possuíam sobre a história das sociedades em questão, refletiam em maior ou menor grau o mal estar de usas próprias experiências traumáticas e dos projetos de futuro que defendiam.

Por isso, ao construir a memória do passado, o fazem de modo a reconhecer seus próprios erros ou a passividade da sociedade. Em um primeiro momento, seu discurso foi na direção da conciliação como uma forma de inserir-se novamente na sociedade e voltar a participar dos debates públicos, o que significou, na maior parte dos casos, em esquecer os crimes da ditadura. Mesmo aqueles que tiveram uma participação mais combativa no período das transições e participaram de diversas comissões de direitos humanos e da recuperação dos casos de repressão, assumiram uma atitude de cautela em relação a justiça de transição. O Cardeal Paulo Evaristo Arns, por exemplo, no prólogo do livro "Brasil Nunca Más" advertiu que o informe não tinha o objetivo de apontar ou julgar os culpados pela repressão, mas de conhecer a verdade para nunca mais acontecer: "não era objetivo da pesquisa organizar nenhum sistema de provas para exibição em um futuro Nuremberg brasileiro. Não nos animava qualquer sentimento de revanche ... o único propósito era de contribuir na construção do país, de una sociedade, de uma terra onde a dignidade da pessoa humana seja respeitada como um bem sagrado. ${ }^{229}$.

${ }^{28}$ Idem, p. 17.

${ }^{29}$ ARNS, D. Evaristo. Brasil nunca mais. Introdução. Petrópolis: Ed. Vozes, 1985. P. XVIII. 
No período imediatamente posterior à crise das ditaduras, mesmo na Argentina, onde a ditadura teve um fim sem pacto e o tema dos direitos humanos esteve mais evidenciado, a moderação e a cautela foram mais comuns entre os intelectuais do que a ousadia e a temeridade.

\section{Debates prediletos na transição}

Os espaços culturais argentinos e brasileiros foram se reorganizando em torno de revistas ${ }^{30}$ culturais, políticas e acadêmicas que surgiram ou foram recuperadas, e nos ambientes acadêmicos, institutos de pesquisa e universidades. Outros ambientes, tais como o "Club de Cultura Socialista", na Argentina, 1984, ou o Centro de Estudos de Cultura Contemporânea (CEDEC), da Universidade de São Paulo, fundado em 1976, ou o Centro Brasileiro de Análise e Planejamento (CEBRAP), fundado em 1969, também foram importantes espaços de discussão sobre o processo de redemocratização nos dois países.

Cautelosos, os intelectuais brasileiros e argentinos discutiam menos a revolução e o socialismo e mais a democracia. Sobre a Argentina, Portantiero $^{31}$ se refere da seguintemaneiraaos temas de preferência das esquerdas no período de transição: "Frente a una realidad trágica que dejó atrás el optimismo de 1970, que no coloca en la agenda de las próximas horas la "actualidad de la revolución", el pensamiento tiende a hacerse más prudente: temas que para las izquierdas fueron casi siempre motivo de manipulación, aparecen ahora cargados de sentido sustancial. Por ejemplo, el de la democracia." 32 .

No Brasil, o fim da ditadura, a anistia e o retorno dos exilados foram marcados pela necessidade de readequação dos debates acerca do socialis-

\footnotetext{
${ }^{30}$ Entre as revistas destacam-se Punto de Vista, Controversias, Cadernos CEBRAP, Civilização Brasileira, Paz e Terra, mas também há que mencionar jornais de organizações revolucionárias que reuniram grande parte dos intelectuais brasileiros e argentinos, tais como Em Tempo, Jornal da Convergência Socialista, Tribuna Operária e Classe Operária, no Brasil; na Argentina, alguns periódicos como Nueva Hora, Ciudad Futura, entre outros.

${ }^{31}$ PORTANTIERO, Juan Carlos. De la crisis del país popular a la reorganización del país burguês. Cuadernos de Marcha. México, segunda época, año I, n. 2, Julio/agosto de 1979.

${ }^{32}$ Idem, P. 11.
} 
mo, da Revolução Brasileira e da democracia. A derrota da luta revolucionária não arrefeceu os debates sobre a transição ao socialismo que perduraram ao longo dos anos 1980. Ao mesmo tempo, as discussões acerca da democracia foram ganhando mais destaque e adquiriram maior relevância. As transformações do mundo socialista e o fracasso do comunismo determinaram, ao longo dos anos 1990, o abandono gradual da utopia socialista, cuja palavra quase desapareceu do vocabulário das esquerdas brasileiras ${ }^{33}$.

A apropriação de Antônio Gramsci por parte da intelectualidade de esquerda fez parte dessa tendência em abandonar os temas mais sensíveis e que marcaram a polarização dos anos 1960/70. Autores como José Aricó e Juan Carlos Portantiero, na Argentina, Carlos Nelson Coutinho, Leandro Konder e Werneck Vianna, no Brasil, foram alguns dos responsáveis pela assimilação de Gramsci e por uma leitura particular sobre a "revolução passiva", que se refletiu no apoio aos governos Raúl Alfonsin e José Sarney e que revelam o aspecto moderado da transição para uma parte da intelectualidade sul-americana, particularmente os comunistas.

Os ambientes culturais e intelectuais durante o período de transição não estiveram apenas mais afastados dos temas relacionados ao socialismo e à revolução, mas também passaram a produzir críticas e autocríticas em relação ao papel desempenhado pela sociedade civil e pela intelectualidade em particular no período da ditadura. De acordo com Marcelo Ridenti ${ }^{34}$, “Às vezes a (auto) crítica do engajamento dos anos 1960 não foi senão a máscara para o triunfo da concepção (neo) liberal do indivíduo, da sociedade e da política. No lugar do intelectual indignado, dilacerado pelas contradições da sociedade capitalista, agravadas nas condições de subde-

\footnotetext{
${ }^{33}$ Ver Rodrigo Dias que discute as esquerdas brasileiras nos anos 1980 e permite vislumbrar a retomada dos debates acerca da Revolução Brasileira. A Esquerda Brasileira no contexto do fim da Guerra Fria. Mestrado em História. Programa de Pós-Graduação em História, UFRGS, Porto Alegre, 2002 e Imprensa revolucionária dos anos oitenta: os intelectuais e suas formulações sobre a Revolução Brasileira. Doutorado em História. Programa de PósGraduação em História, UFRGS, Porto Alegre, 2011.

${ }^{34}$ RIDENTI, M. In BASTOS, E. R, ROLLAND, D. (Orgs.). Intelectuais: soiedade e política. São Paulo: Cortez, 2003.
} 
senvolvimento, passava a predominar o intelectual profissional competente e competitivo no mercado das idéias, centrado na carreira e no próprio bem-estar individual" "35.

Mas não era apenas isso, alguns intelectuais que nos anos 1960 estavam plenamente engajados em lutas transformadoras, ao retornar do exílio e quando, nos anos 1980, sentiram-se a vontade para expressar suas impressões e ideias, fizeram uma autocrítica relativa à responsabilidade pelo ocorrido nas sociedades argentina e brasileira.

Daniel Aarão Reis Filho ${ }^{36}$ se refere a uma "sintonia entre as políticas adotadas pela ditadura e os interesses de amplos contingentes que sentiam e sentem um grande medo dos de baixo...". Entretanto, segundo o mesmo autor, ao final do período ditatorial, "não há praticamente ninguém que reivindique algum tipo de intimidade com a ditadura que regeu durante tantos anos a sociedade brasileira" ${ }^{37}$.

Beatriz Sarlo ${ }^{38}$ define este estado de espirito de auto-reprovação: "Estamos hoy enfrentados con todo nuestro pasado y, se sabe, allí no todas las condenas ni todas las acusaciones pueden tener a los militares como objeto. Nuestra autobiografía tiene un lugar abierto para nuestras responsabilidades: somos una parte de lo ocurrido en Argentina, y haber sufrido más no es una razón para que en la reconstrucción del pasado nos olvidemos de nosotros, cuya soberbia nos hizo creer, en algunos momentos, que en la claridad de la revolución futura nos habíamos convertido en amos de la historia." 39 .

A mudança no perfil dos intelectuais entre os anos 1960 e 1970 era outro tema aludido pelos intelectuais inconformados, de um lado, com a ideologia da conciliação e, de outro, com o abandono das teses revolucionárias.

\footnotetext{
${ }^{35}$ Idem, p. 206.
}

${ }^{36}$ REIS, Daniel Aatão. Os muitos véus da impunidade: sociedade, tortura e ditadura no Brasil. In: http://www,dhnet.org.br/denunciar/tortura/textos/aarão.htm, acesso em março de 2013, escrito em 1999.

${ }^{37}$ Idem, p. 01.

${ }^{38}$ SARLO, Beatriuz. Uma alucinación dispersa em agonia, in: Revista Punto de Vista. N. 21,1984 .

${ }^{39}$ Idem, p. 2. 
Carlos Altamirano ${ }^{40}$ adverte no mesmo sentido, de que é possível visualizar o deslocamento do modelo de intelectual "total", portador das grandes sínteses, porta-voz do sujeito coletivo - povo, nação, classes oprimidas - para outro tipo de intelectual que busca seu lugar em instâncias mais institucionais: a institucionalidade académica, estatal e vinculada aos meios de comunicação. Alerta para o risco de 'esclerose e moderação', de modo que o intelectual termine sendo "el intérprete de unorden" $"$.

Ruy Mauro Marini ${ }^{42}$ se refere à mudança no perfil dos intelectuais, ocorrida entre a ditadura e o processo de transição: “... a maioria da intelectualidade brasileira de esquerda colaborou, de maneira mais ou menos consciente, com a política oficial, fechando o caminho à difusão dos temas que agitaram a esquerda latino-americana na década de $1970 \ldots$ No Brasil e no resto da América Latina, a disputa pela obtenção dos recursos... reconstituiu a elite intelectual sobre bases totalmente novas, sem qualquer relação com as que - fundadas na radicalização política e na ascensão dos movimentos de massas - a haviam sustentado na década de 1960.”. Com isso, ele tristemente concluiu: "Como quer que fosse esse era o país ao qual eu devia me reintegrar." ${ }^{43}$.

Theotônio dos Santos ${ }^{44}$ também faz referência às dificuldades que enfrentaria no retorno ao Brasil e ensaia uma explicação: "Em 1979 no México havia organizado, na Divisão de Pós Graduação de Economia da UNAM, um debate sobre a volta da democracia no Brasil em que trouxemos vários cientistas sociais brasileiros. Neste debate, comecei a sentir que a minha volta não seria tão bem recebida. Havia grandes divergências entre a minha visão do processo de democratização de nosso país e das implicações econômico-sociais e, sobretudo, de política econômica, em

\footnotetext{
${ }^{40}$ ALTAMIRANO, Carlos. Op. cit.

${ }^{41}$ Idem, p. 4.

${ }^{42}$ MARINI, Ruy Mauro. Memória. In http://www.marini-escritos.unam. mx/001 memoria port,htm. Acesso em 30.06.2009.

${ }^{43}$ Idem, p. 36.

${ }^{44}$ SANTOS, Theotônio. Memorial. Digitado, 1994, 138 p. 
relação àquela que vinha presidindo grande parte dos pensadores sociais no Brasil.".

A dificuldade de reintegração dos exilados aos ambientes acadêmicos esteve relacionada às transformações sofridas pelo ensino superior no Brasil e na Argentina naquele período, à adaptação das elites acadêmicas ao regime autoritário, à cooptação de intelectuais de esquerda através do financiamento de pesquisas, de bolsas e aos sistemas de promoção na carreira universitária.

Marini faz referência ao papel desempenhado pela política cultural da ditadura no padrão imposto aos intelectuais brasileiros. Segundo ele, "Essa política teria resultado, porém, menos exitosa se mais e mais intelectuais não houvessem sido cooptados pelo sistema, inclusive aqueles que se situavam em oposição ao regime. Ocorreu no país um fenômeno curioso: intelectuais de esquerda, que chegavam a ocupar posições em centros acadêmicos, ou que os criavam com o fim precípuo de ocupar posições, estabeleciam à sua volta uma rede de proteção contra o assédio da ditadura e utilizavam sua influência sobre a destinação de verbas e de bolsas para consolidar o que haviam conquistado, atuando com base em critérios sumamente grupais. Entretanto, o que aparecia, originalmente, como autodefesa e solidariedade tornou-se, com o correr do tempo... uma vocação irresistível para o corporativismo, a cumplicidade e o desejo de exclusão de todo aquele... que ameaçasse o poder das pessoas e grupos beneficiários desse processo... resultava proveitoso... monopolizar e personalizar as ideias que floresciam na vida intelectual da região, adequando-as previamente aos limites estabelecidos pela ditadura. Neste contexto, a maioria da intelectualidade brasileira de esquerda colaborou, de maneira mais ou menos consciente, com a política oficial, fechando o caminho à difusão dos temas que agitaram a esquerda latino-americana na década de 1970..." ${ }^{45}$.

A respeito dessa visão de Ruy Mauro Marini sobre o processo de cooptação dos intelectuais de esquerda no período da ditadura, Celso Furtado

${ }^{45}$ MARINI, Ruy Mauro. Op. cit., 1991, p. 37. 
procura definir os intelectuais latino-americanos em entrevista concedida à Aspásia Camargo e Maria Andréa Loyola ${ }^{46}$ : "Se tivesse de, em poucas linhas, traçar o retrato típico do intelectual nos nossos países subdesenvolvidos, eu diria que ele reúne em si $90 \%$ de malabarista e $10 \%$ de santo. Assim, a probabilidade de que se corrompa... é de 9 em 10. Se escapa à regra, será implacavelmente perseguido..." ${ }^{47}$

\section{Qual democracia?}

Outro dilema relativo à transição nos dois países diz respeito à democracia e suas relações com a modernização e com o socialismo. Já se aludiu à assimilação das teses de Gramsci sobre a revolução pacífica e sobre a conquista de consensos para construção de espaços hegemônicos. Porém, ainda que prudentes, a maior parte dos intelectuais brasileiros e argentinos não se sentiam confortáveis diante de qualquer democracia.

Francisco Weffor ${ }^{48}$ enfatizava a necessidade de questionar-se sobre a eficácia da democracia política: "O fato de que lutemos pela democracia política como um valor em si não pode (nem deve) impedir-nos de reconhecer que a democracia política tem que fazer a sua prova de competência e de eficácia".

Juan Carlos Portantiero ${ }^{49}$, por sua parte, advertia que a discussão sobre o tipo de democracia estava diretamente relacionada com a questão da crise econômica e das propostas de desenvolvimento emanadas dos setores dominantes: "Por un lado, la democracia formal ya no aparece como un puro reclamo liberal. Por el otro, la hondura de la crisis y el monto de los cambios que el grupo dominante quiere efectuar en la Argentina, obligan

${ }^{46}$ CAMARGO, Aspásia \& LOYOLA, Maria Andrés. Celso Furtado. Coleção Pensamento Contemporâneo. Rio de Janeiro: UERJ, 2002, v. 3.

${ }^{47}$ Idem, p. 36.

${ }^{48}$ WEFFORT. F. Op. cit., p. 94.

${ }^{49}$ PORTANTIERO, Juan Carlos. La democracia difícil Proyeto democrático y movimiento popular, in: Revista Controversia. Para el examen de la realidad argentina. México, n. 1, octubre de 1979.

208 
a pensar en cuáles serían las bases para la estructuración de un proyecto democrático que sea a la vez político y social, formal y fundamental. ... habría que ver cuáles son en esta hora las condiciones sociales que pueden hacer posible a la democracia; qué "estilo de desarrollo" le es afín y cuál le es irremediablemente hostil." ${ }^{, 50}$.

A redefinição da ordem econômica internacional estava no horizonte das preocupações dos intelectuais de esquerda que discutiam o tema da democracia. Intelectuais brasileiros e argentinos tinham inquietações semelhantes no que se refere à crise econômica que atingia a América do Sul, e particularmente seus próprios países: "Está evidente que a construção da democracia política tem que se relacionar com o desenvolvimento econômico e social de nossos países. Mar também é necessário deixar claro que se entendemos a democracia como um valor em si, isso não quer dizer que a tomemos 'em lugar de' alguma outra coisa." 51 .

As ressalvas em relação à "democracia como um valor em si" partiam de intelectuais latino-americanos que, diferentemente de Weffort, não se conformavam com a ideia de priorizar a democracia e o desenvolvimento em relação ao socialismo e à consciência de pertencer ao elo débil do sistema capitalista mundial. Agustin $\mathrm{Cueva}^{52}$ foi um destes intelectuais que se posicionava contra o que ele chamou de "democracia sin adjetivos" ( $\mathrm{p}$. 28). Para ele era absolutamente primordial discutir a distinção entre a democracia formal e o seu conteúdo. Se para Weffort, “...a disjunção, célebre na América Latina, entre o caráter 'formal' da democracia e o seu conteúdo 'substantivo' encontra, na época atual, o momento de uma possível superação" 53 , para Cueva ${ }^{54}$, por outra parte, a possibilidade de superar a contradição não era vista com tanta naturalidade. Segundo ele, a democracia política formal não seria suficiente para acabar com as desigualdades

\footnotetext{
${ }^{50}$ Idem, p. 07.

${ }^{51}$ WEFFORT, F. Op. cit., p. 95.

${ }^{52}$ CUEVA, A. Tempos conseradores. São Paulo: HUCITEC, 1988.

${ }^{53}$ WEFFORT, F. Op. cit., p. 105.

${ }^{54}$ CUEVA, A. Op. cit.
} 
sociais, a miséria e a dependência, pois estas eram características estruturais do sistema capitalista na periferia e a ausência de democracia - e a violência - era o modo de o sistema manter as massas populares controladas.

Os mesmos autores que nos anos 1960 e 1970 teorizavam sobre a disjuntiva Feudal Versus Capitalista para caracterizar as sociedades coloniais latino-americanas e, ao mesmo tempo, manifestar suas convicções acerca da proximidade do socialismo, nos anos 1980, em contexto pós-marxista, posicionavam-se acerca das possíveis contradições entre o socialismo e a democracia: “...larelación entre democracia y socialismo está enelmismo centro de la polémica actualdel marxismo contemporáneo. Más aún: quisiera decir que si el marxismo no resuelve esa dificultad de la interacción entre ambos términos estará agotado como programa de la revolución contemporánea y quedará confinado como una teoría estatista de la acumulación del capital en sociedades atrasadas" 55 .

No período de transição, conciliar democracia e socialismo poderia significar muito para os intelectuais que voltaram do exílio e para aqueles que conseguiram se permanecer no Brasil e na Argentina sem conseguir se manifestar. Significava, por exemplo, dar resposta à crise que se abatera sobre o "socialismo real", com o debacle da URSS. Significava, igualmente, reconquistar o prestígio do marxismo, apesar da derrota do socialismo na prática, procurando reconstituir assim a unidade entre teoria e prática. Intelectuais como Weffort ${ }^{56}$, Aricó, Portantiero e Carlos Nelson Coutinho estiveram mais inclinados a valorização da democracia como "valor em si"

José Aricó dissertou sobre o tema: "Sobre los pilares de las ideas de "socialismo" y de "democracia" (y de democracia formal, acentuaría) puede constituirse esa síntesis de la que requiere hoy el movimiento socialista para reconquistar la unidad entre teoría y práctica, ética y política, ser y deber ser que constituyó durante muchos años la razón de su capacidad expansiva y transformadora, el secreto de su fuerza mítica." ${ }^{57}$.

\footnotetext{
${ }^{55}$ PORTANTIERO, Juan Carlos. De la crisis..., op. cit., p. 12.

${ }^{56}$ WEFFORT, F. Op. cit..

${ }^{57}$ ARICÓ, José Maria. La crisis del marxismo. In Controversia. Para el examen de la realidad argentina. México, octubre de 1979, p. 13.
} 
Carlos Nelson Coutinho ${ }^{58}$ aprofundava essa tendência à valorização da democracia como valor universal e inquestionável: “... o valor da democracia não se limita a áreas geográficas. Pois se há por sua vez algo de universal nas reflexões teóricas e na prática política do que é hoje chamado de eurocomunismo, esse algo é precisamente o modo novo - um modo dialeticamente novo, não uma novidade metafisicamente concebida como ruptura absoluta - de conceber essa relação entre socialismo e democracia." 59 .

Para a intelectualidade marxista e de esquerda parecia evidente que se poderia estabelecer uma relação original entre socialismo e democracia, antes impensada, mas para alguns outros intelectuais, tais como Cueva, Marini, Dos Santos e Fernandes, a relação entre democracia e socialismo deveria estar assentada, de um lado, na crítica aos equívocos da URSS, mas também na crítica à democracia formal burguesa, de modo que não se abandonasse a utopia do socialismo.

As palavras de Florestan Fernandes ${ }^{60}$ ilustram muito bem este tipo de posicionamento: "Carecemos com premência da democracia. Mas de uma democracia que não seja o túmulo do socialismo proletário e dos sonhos de igualdade com liberdade das classes trabalhadoras" ${ }^{61}$. Fernandes menciona Rosa de Luxemburgo e Gramsci para explicar a crítica que fizeram às tentativas socialdemocratas de "degradação aburguesada do socialismo" "62, que segundo ele estava em pleno vigor na transição brasileira. Segundo suas palavras, "As dificuldades e adulteração do marxismo, por causa do isolamento e das consequências imprevistas da Revolução Russa, suscitavam uma aparência de verdade às versões da 'democracia acima de tudo' do farisaísmo pequeno-burguês e intelectualista. ${ }^{.63}$.

\footnotetext{
${ }^{58}$ COUTINHO, Carlos Nelson. A democaria como valor universal. Encontros com a Civilziação Brasileira. Rio de Janeiro, n. 9. 1979.

${ }^{59}$ Idem, p. 33.

${ }^{60}$ FERNANDES, Florestan. A transição prolongada: o período pós-constitucional. São Paulo: Cortez, 1990.

${ }^{61}$ Idem, p. 159.

${ }^{62}$ Idem, p. 157.

${ }^{63}$ Idem, p. $157 / 158$.
} 
Estes últimos excertos de Florestan Fernandes estão em pleno desacordo com Weffort ${ }^{64}$ (citado acima) ou com Aricó ${ }^{65}$, para quem: "En esta desaparición de las fronteras fijas entre democracia radical y socialismo, el mito de la democracia, de la invención democrática, puede convertirse tal vez en el mito laico que unifique a las fuerzas sociales en pro de su recomposición. Pienso que la conquista de la democracia como un elemento sustantivo en sí mismo, como un objetivo ideal que se agote en sí mismo debe tender a transformarse en el nudo central de la actual reconstrucción de la cultura de izquierda en América Latina." ${ }^{\prime 66}$.

A mesma disputa que dividia os intelectuais brasileiros e argentinos em torno das contradições entre democracia e socialismo, evidenciadas nos excertos mencionados anteriormente, também apontava na direção dos processos de reconciliação com o passado e nas possibilidades de acomodação - aggiornamento ${ }^{67}$ - com a nova situação dos dois países.

Nos anos 1980, o Brasil e a Argentina tinham se modificado muito, mas existiam múltiplos passados, dos vencidos, dos vencedores, daqueles que haviam sofrido o exílio e dos que permaneceram nos países, dos que haviam sofrido a tortura e repressão e dos que passaram incólumes pelo processo. Muitos destes processos ainda estavam em andamento, o que significa que eram passados que não haviam passado. E muitos deles eram irreconciliáveis entre si.

A impossibilidade de reconciliação dos múltiplos passados - as mais diversas formas através das quais os intelectuais brasileiros e argentinos vivenciaram o período ditatorial e a fase das transições à democracia - es-

${ }^{64}$ WEFFORT, F. Op. cit., p. 105.

${ }^{65}$ ARICÓ, José Maria. El destino se llam democracia. In: CRESPO, Horácio. José Arcó. Entrevistas (1974-1991). Córdoba: Ediciones del Centro de Estudios Avanzados, Universidad Nacional de Córdoba, 1999. Entrevista de 1983.

${ }^{66}$ Idem, p. 29.

${ }^{67}$ Aggiornamento é um termo italiano, foi utilizado durante o Concílio Vaticano II, popularizada pelo Papa João XXIII para explicar a necessidade de a Igreja se adaptar os princípios católicos ao mundo atual e moderno. Pode ser usada, neste caso, pois se refere a uma espécie de acomodação forçada! 
teve evidenciada nas formas como ocorreu o reingresso de cada intelectual mencionado nos espaços acadêmico, cultural e político após a anistia. Para ter acesso privilegiado a esses lugares, foi decisiva a adesão dos pensadores brasileiros e argentinos à ideologia da conciliação, o que não caracterizava, nem de longe, o pensamento unânime dos intelectuais aqui mencionados. 
